\title{
Insulin-like growth factor (IGF)-I and IGF binding proteins axis in diabetes mellitus
}

\author{
Min Sun Kim, MD, \\ Dae-Yeol Lee, MD
}

Department of Pediatrics, Chonbuk National University Medical School, Research Institute of Clinical Medicine of Chonbuk National UniversityBiomedical Institute of Chonbuk National University Hospital, Jeonju, Korea
Received: 23 June, 2015

Accepted: 24 June, 2015

Address for correspondence:

Dae-Yeol Lee, MD

Department of Pediatrics, Chonbuk

National University Children's

Hospital, 20 Geonji-ro, Deokjin-gu,

Jeonju 561-712, Korea

Tel: +82-63-250-1469

Fax: +82-63-250-1464

E-mail: leedy@jbnu.ac.kr
Increasing evidence suggests an important role of the insulin-like growth factor (IGF)-IGF binding protein (IGFBP) axis in the maintenance of normal glucose and lipid metabolism. Significant changes occur in the local IGF-I-IGFBPs environment in response to the diabetic milieu. A significant reduction of serum IGF-I levels was observed in patients with type 1 diabetes mellitus (T1DM). Inversely, considerably increased serum levels of IGF-I and IGFBP-3 levels were detected in individuals with glucose intolerance including T2DM. Recently, several prospective studies indicated that baseline levels of IGF-I and IGFBPs are associated with the development of diabetes. These findings suggest that disturbances in insulin and IGF-I-IGFBP axis can affect the development of glucose intolerance including diabetes.

Keywords: Diabetes mellitus, Insulin-like growth factor I, Insulin-like growth factor binding protein 1, Insulin-like growth factor binding protein 3, Lipid metabolism

\section{Introduction}

The insulin-like growth factor (IGF)-system plays critical roles in regulating the somatic growth in an endocrine manner and in the proliferation as well as differentiation of normal and malignant cells in a paracrine-autocrine manner ${ }^{1)}$. IGF-I has a significant structural homology with proinsulin. However, IGF-I and insulin have distinct receptors, which are tyrosine kinase-containing receptors with approximately $60 \%$ of amino acid sequence homology $y^{2,3)}$. The affinity of the IGF receptor for IGF-I is 1,000 times greater than that for insulin, while the insulin receptor shows 100 folds greater affinity towards insulin than that for IGF-I. The IGF system includes growth hormone (GH), IGF-I/II peptide, type 1 and 2 receptors, IGF binding proteins (IGFBPs), and IGFBP proteases ${ }^{4-6)}$. A total of six high-affinity binding proteins have been identified (IGFBP-1 to -6). The hepatic IGF-I circulates almost entirely in the IGFBP-bound form. IGFBP-3, a major IGFBP species in the serum, binds more than $90 \%$ of the circulating IGF-I in a large ternary complex consisting of IGFBP-3, acid labile subunit, and IGFs' ${ }^{7}$. IGFBP-3 also has been shown to stimulate cell growth and carry out other functions in an IGF-independent manner in a variety of cell types ${ }^{8)}$.

\section{The IGF-I-IGFBP axis and glucose and lipid metabolism}

Although IGF-I is classically considered an important growth factor, it also has major metabolic effects. This metabolic effect of IGF-I is to provide a signal to cells that adequate nutrient is available to avoid apoptosis, enhance cellular protein synthesis, enable cells to undergo hypertrophy in response to an appropriate stimulus and stimulate cell division. Insulin is the primary regulator of glucose metabolism, but the IGF axis also might play a role in maintaining glucose homeostasis. Many laboratory studies have found that IGF-I can promote glucose uptake in peripheral tissues ${ }^{9,10)}$. It has been shown also that IGF-I can suppress hepatic glucose production ${ }^{11,12}$. Furthermore, a significant positive correlation between the sensitivity to insulin 
and endogenous IGF-I concentration in patients with varying degree of glucose intolerance was reported ${ }^{13)}$. In addition, exogenous IGF-I administration has been shown to reduce serum glucose levels in healthy individuals and patients with various glucose intolerance states ${ }^{9,14}$. These findings indicate that serum IGF-I and IGFBPs levels may influence the risk of developing type 2 diabetes mellitus (T2DM).

IGFBPs may also have a role in glucose metabolism. In particular, IGFBP-1 may acutely regulate glucose levels through its effects on free IGF-I ${ }^{15)}$. Insulin suppresses IGFBP- 1 gene transcription and changes in insulin concentration are correlated with relatively acute changes in circulating IGFBP-1 levels ${ }^{16}$. Exogenous IGFBP-1 injections have been shown to cause reductions in free IGF-I and circulating glucose levels ${ }^{17}$. In addition, reduced IGFBP-1 synthesis and circulating levels are observed in obesity ${ }^{18)}$. IGFBP-3, the most abundant IGFBP in circulation, may play a role in glucose regulation, and its metabolic effects are largely opposite to those of IGF- ${ }^{19}{ }^{19}$. IGFBP-3 inhibits the biological activity of IGF-I by sequestrating IGF-I into a circulating reservoir, thereby reducing levels of free IGF-I in circulation and increases the risk of diabetes ${ }^{14,19)}$. It has been reported that IGFBP-3 binds to the nuclear receptor, RXR- $\alpha$, which interacts with the peroxisome proliferator-activated receptor-gamma nuclear protein that is involved in the regulation of glucose and lipid metabolism ${ }^{20)}$. Studies on transgenic animal showed that overexpression of IGFBP-3 was associated with fasting hyperglycemia and impaired glucose tolerance $(\mathrm{IGT})^{21)}$.

The IGF axis may also affect lipid metabolism. Although mature adipocytes are devoid of IGF-I receptor, preadipocytes express them in abundance and IGF-I stimulates preadipocyte differentiation ${ }^{10)}$. In vitro studies have shown that IGF-I may have insulin-like effects in promoting the uptake of free fatty acid (FFA) into adipocytes, hepatocytes, and stimulating lipogenesis ${ }^{10,22)}$. Human studies reported that exogenous IGF-I administration significantly lowered FFA levels ${ }^{23,24)}$. Overall, FFA uptake is thought to be the primary effect of the IGF axis on FFA turnover, whereas the promotion of lipogenesis plays only a minor role. In addition, a number of studies have shown an independent association between low levels of IGF-I and cardiovascular disease ${ }^{25,26)}$.

\section{The IGF-I-IGFBP axis and diabetes mellitus}

The GH-IGF-I axis has been reported to be altered in patients with type 1 diabetes mellitus (T1DM) ${ }^{27}$. T1DM is a disease of insulin deficiency that results from the autoimmune-mediated destruction of pancreatic beta cells. Whereas spontaneous GH secretion is increased, low serum IGF-I levels have been reported, suggesting that $\mathrm{GH}$ resistance is present in T1DM. The major part of serum IGF-I derives from liver in response to GH stimulation, and IGF-I synthesis in the liver is also regulated by insulin ${ }^{28)}$. Therefore, the lack of adequate intraportal insulin supply leads to a major suppression of hepatic IGF-I biosynthesis in DM. Furthermore, a low portal vein insulin concentration contributes to elevated IGFBP-1 levels in patients with T1DM ${ }^{29}$. IGFBP-3 is the principal binding protein of IGF-I in serum, and its concentration is increased in response to GH. Changes in IGFBP profiles result in an alteration of IGF-I availability in DM. These abnormalities not only exacerbate hyperglycemia in T1DM patients, but may contribute to the pathogenesis of diabetes-specific complications ${ }^{30)}$. Although serum IGF-I axis has been largely studied in T1DM patients, there is limited evidence in the literature of a possible relationship between serum IGF-I and IGFBP-3 levels and the clinical variables associated with T1DM.

Table 1. Selected studies on serum IGF-IGFBP axis in patients with diabetes mellitus

\begin{tabular}{|c|c|c|c|c|c|}
\hline Study & Type of DM & Subject & Serum IGF-I & Serum IGFBPs & Remark \\
\hline Munoz et al. ${ }^{35)}$ & 1 & Children & $|G F-|(T) \downarrow$ & $\begin{array}{l}\text { IGFBP-1 } \uparrow \\
\text { IGFBP-3 } \rightarrow\end{array}$ & $\begin{array}{l}\text { IGF-I levels negatively correlate with } \mathrm{HbA1c} \\
\text { IGFBP-1 levels positively correlate with } \mathrm{HA} 1 \mathrm{c}\end{array}$ \\
\hline Dunger et al. ${ }^{38)}$ & 1 & Children & $|G F-|(T) \downarrow$ & $\begin{array}{l}\text { IGFBP-1 } \uparrow \\
\text { IGFBP-3 } \downarrow\end{array}$ & $\begin{array}{l}\text { Low IGF-I levels may be associated with diabetic microangiopathic } \\
\text { complication }\end{array}$ \\
\hline Cinaz et al. ${ }^{39)}$ & 1 & Children & $|G F-|(T) \downarrow$ & IGFBP-3 $\downarrow$ & $\begin{array}{l}\text { Low IGFBP-3 levels are associated with increased IGFBP-3 protease } \\
\text { activity }\end{array}$ \\
\hline Wedrychowicz et al. ${ }^{40)}$ & 1 & Children & $|G F-|(T) \downarrow$ & $\begin{array}{l}\text { IGFBP-1 } \uparrow \\
\text { IGFBP-3 } \downarrow\end{array}$ & IGFBP-1 levels may be associated with diabetic complications \\
\hline Bereket et al. ${ }^{41)}$ & 1 & Children & ND & IGFBP-3 $\downarrow$ & $\begin{array}{l}\text { Increased IGFBP-3 proteolysis is associated with the catabolic state } \\
\text { induced by insulin deficiency }\end{array}$ \\
\hline Kim et al. $^{42)}$ & 1 & Children & $|G F-|(T) \downarrow$ & IGFBP-3 $\rightarrow$ & IGFBP-3 levels positively correlate with $\mathrm{HbA1c}$ \\
\hline Frystyk et al. ${ }^{33)}$ & 2 & Adult & $|G F-|(F) \uparrow$ & $\begin{array}{l}\text { IGFBP-1 } \uparrow \\
\text { IGFBP-3 } \uparrow\end{array}$ & $\begin{array}{l}\text { The impact of T2DM on GH/IGF system is different from that of } \\
\text { T1DM }\end{array}$ \\
\hline Rajpathak et al. ${ }^{32)}$ & 2 & Adult & $|G F-|(F) \uparrow$ & IGFBP-1 $\downarrow$ & Low IGFBP-1 levels are associated with the increased risk of DM \\
\hline Payne et al. ${ }^{43)}$ & 2 & Adult & $|G F-|(T) \rightarrow$ & ND & |GF-I levels are not associated with diabetic complications \\
\hline Kim et al. $^{44)}$ & 2 & Children & $|G F-|(T) \uparrow$ & IGFBP-3 $\uparrow$ & IGF-1 and IGFBP-3 levels positively correlate with $\mathrm{HbA1c}$ \\
\hline Rajpathak et al. .4,a) $^{2}$ & 2 & Adult & $|G F-|(F) \downarrow$ & $\begin{array}{l}\text { IGFBP-1 \& } 2 \downarrow \\
\text { IGFBP-3 } \uparrow\end{array}$ & $\begin{array}{l}\text { IGF-I(F) and IGFBP-1\&2 levels are negatively associated with DM } \\
\text { IGFBP-3 levels are positively associated with DM }\end{array}$ \\
\hline
\end{tabular}


Several lines of evidence suggest that the IGF-I-IGFBPs axis has an important role in the maintenance of normal glucose homeostasis and may contribute to the etiopathogenesis of $\mathrm{T}_{2} \mathrm{DM}^{31,32)}$. Although there are conflicting data regarding the relationship between IGF-I and IGFBPs levels and T2DM, many studies have found that free IGF-I and IGFBP-3 concentrations are elevated, whereas, IGFBP-1 levels are low in subjects with IGT and T2DM ${ }^{32,33)}$. The association of high serum IGF-I level with IGT and DM may be either causal or pathological. Early T2DM and IGT are usually characterized by insulin resistance and hyperinsulinemia. Insulin stimulates hepatic IGF-I synthesis, suppresses hepatic IGFBP-1 synthesis, and increases GH expression in the liver, which could lead to increase circulating concentration of total or free IGF-I. Therefore, high serum IGF-I levels in subjects with T2DM may be due to high insulin concentrations rather than because of some specific biological impact of IGF axis on DM pathogenesis. However, elevated IGFBP-1 levels in patients with T2DM have been frequently reported. This would be expected because the loss of hepatic sensitivity to insulin and decreased insulin levels allow for uncontrolled IGFBP- 1 secretion. Recently, a large prospective study found strong associations of incident diabetes with baseline levels of IGFBP-1, 2, 3 and free IGF-I suggesting a modulatory effect of the IGF-IGFBP axis on the risk of $\mathrm{DM}^{34)}$ These data indicate a protective effect of IGF-I against the development of IGT/T2DM. Although serum IGF-I levels were thought to be dependent on the degree of glucose control in patients with T2DM, prior studies examining clinical correlations of IGF-I or IGFBP-3 levels in diabetes have yielded mixed results ${ }^{35-37)}$. Table 1 depicts results of several studies that examined serum IGF-I and IGFBP-1-3 levels and association of the IGF-I axis with clinical variables in patients with DM.

\section{Conclusions}

IGF-I is an important growth factor and has major metabolic effects. Many studies suggest that the IGF-I-IGFBPs axis is important for the maintenance of normal glucose homeostasis and its disturbance are associated with the risk of diabetes. Cross-sectional studies indicate that IGF-I and IGFBPs levels are altered in patients with obesity and glucose intolerance including DM. Furthermore, large prospective studies found strong associations between baseline IGF-I and IGFBPs levels and the risk of developing DM. In addition, the use of recombinant human IGF-I to improve peripheral insulin sensitivity in subjects with DM has been promising. However, further studies are necessary to reveal biological mechanism of IGF-I-IGFBP-3 axis impact on the development of glucose intolerance and T2DM.

\section{Conflict of interest}

No potential conflict of interest relevant to this article was reported.

\section{References}

1. Daughaday WH. The possible autocrine/paracrine and endocrine roles of insulin-like growth factors of human tumors. Endocrinology 1990;127:1-4.

2. Ullrich A, Gray A, Tam AW, Yang-Feng T, Tsubokawa $\mathrm{M}$, Collins C, et al. Insulin-like growth factor I receptor primary structure: comparison with insulin receptor suggests structural determinants that define functional specificity. EMBO J 1986;5:2503-12.

3. Clemmons DR. Involvement of insulin-like growth factor-I in the control of glucose homeostasis. Curr Opin Pharmacol 2006;6:620-5.

4. Le Roith D. Seminars in medicine of the Beth Israel Deaconess Medical Center. Insulin-like growth factors. N Engl J Med 1997;336:633-40.

5. Baxter RC, Martin JL. Binding proteins for the insulin-like growth factors: structure, regulation and function. Prog Growth Factor Res 1989;1:49-68.

6. Jones JI, Clemmons DR. Insulin-like growth factors and their binding proteins: biological actions. Endocr Rev 1995;16:3-34.

7. Jogie-Brahim S, Feldman D, Oh Y. Unraveling insulin-like growth factor binding protein-3 actions in human disease. Endocr Rev 2009;30:417-37.

8. Walker GE, Kim HS, Yang YF, Oh Y. IGF-independent effects of the IGF superfamily. In: Le Roith D, Zumkeller W, Baxter R, editors. Insulin-like growth factors. Austin (Tx): Landes Biosciences, 2004:1-22

9. Moses AC, Young SC, Morrow LA, O'Brien M, Clemmons DR. Recombinant human insulin-like growth factor I increases insulin sensitivity and improves glycemic control in type II diabetes. Diabetes 1996;45:91-100.

10. Scavo LM, Karas M, Murray M, Leroith D. Insulin-like growth factor-I stimulates both cell growth and lipogenesis during differentiation of human mesenchymal stem cells into adipocytes. J Clin Endocrinol Metab 2004;89:3543-53.

11. Laager R, Ninnis R, Keller U. Comparison of the effects of recombinant human insulin-like growth factor-I and insulin on glucose and leucine kinetics in humans. J Clin Invest 1993;92:1903-9.

12. Jacob R, Barrett E, Plewe G, Fagin KD, Sherwin RS. Acute effects of insulin-like growth factor I on glucose and amino acid metabolism in the awake fasted rat. Comparison with insulin. J Clin Invest 1989;83:1717-23.

13. Sesti G, Sciacqua A, Cardellini M, Marini MA, Maio $\mathrm{R}$, Vatrano $\mathrm{M}$, et al. Plasma concentration of IGF-I is independently associated with insulin sensitivity in subjects with different degrees of glucose tolerance. Diabetes Care 2005;28:120-5.

14. Russell-Jones DL, Bates AT, Umpleby AM, Hennessy TR, Bowes SB, Hopkins KD, et al. A comparison of the effects of 
IGF-I and insulin on glucose metabolism, fat metabolism and the cardiovascular system in normal human volunteers. Eur J Clin Invest 1995;25:403-11.

15. Katz LE, DeLeon DD, Zhao H, Jawad AF. Free and total insulin-like growth factor (IGF)-I levels decline during fasting: relationships with insulin and IGF-binding protein-1. J Clin Endocrinol Metab 2002;87:2978-83.

16. Luo J, Murphy LJ. Differential expression of the insulin-like growth factor binding proteins in spontaneously diabetic rats. J Mol Endocrinol 1992;8:155-63.

17. Lang CH, Vary TC, Frost RA. Acute in vivo elevation of insulin-like growth factor (IGF) binding protein-1 decreases plasma free IGF-I and muscle protein synthesis. Endocrinology 2003;144:3922-33.

18. Manetta J, Brun JF, Maimoun L, Callis A, Prefaut C, Mercier J. Effect of training on the GH/IGF-I axis during exercise in middle-aged men: relationship to glucose homeostasis. Am J Physiol Endocrinol Metab 2002;283:E929-36.

19. Muzumdar RH, Ma X, Fishman S, Yang X, Atzmon G, Vuguin P, et al. Central and opposing effects of IGF-I and IGF-binding protein-3 on systemic insulin action. Diabetes 2006;55:2788-96.

20. Schedlich LJ, Le Page SL, Firth SM, Briggs LJ, Jans DA, Baxter RC. Nuclear import of insulin-like growth factorbinding protein- 3 and -5 is mediated by the importin beta subunit. J Biol Chem 2000;275:23462-70.

21. Silha JV, Gui Y, Murphy LJ. Impaired glucose homeostasis in insulin-like growth factor-binding protein-3-transgenic mice. Am J Physiol Endocrinol Metab 2002;283:E937-45.

22. Pratipanawatr T, Pratipanawatr W, Rosen C, Berria R, Bajaj M, Cusi K, et al. Effect of IGF-I on FFA and glucose metabolism in control and type 2 diabetic subjects. Am J Physiol Endocrinol Metab 2002;282:E1360-8.

23. Laager R, Keller U. Effects of recombinant human insulinlike growth factor I and insulin on counterregulation during acute plasma glucose decrements in normal and type 2 (non-insulin-dependent) diabetic subjects. Diabetologia 1993;36:966-71.

24. Turkalj I, Keller U, Ninnis R, Vosmeer S, Stauffacher W. Effect of increasing doses of recombinant human insulin-like growth factor-I on glucose, lipid, and leucine metabolism in man. J Clin Endocrinol Metab 1992;75:1186-91.

25. Laughlin GA, Barrett-Connor E, Criqui MH, Kritz-Silverstein $\mathrm{D}$. The prospective association of serum insulin-like growth factor I (IGF-I) and IGF-binding protein-1 levels with all cause and cardiovascular disease mortality in older adults: the Rancho Bernardo Study. J Clin Endocrinol Metab 2004;89:114-20.

26. Sandhu MS, Heald AH, Gibson JM, Cruickshank JK, Dunger DB, Wareham NJ. Circulating concentrations of insulin-like growth factor-I and development of glucose intolerance: a prospective observational study. Lancet 2002;359:1740-5.

27. Dunger DB, Cheetham TD, Holly JM, Matthews DR. Does recombinant insulin-like growth factor I have a role in the treatment of insulin-dependent diabetes mellitus during adolescence? Acta Paediatr Suppl 1993;388:49-52.

28. Boni-Schnetzler M, Schmid C, Meier PJ, Froesch ER. Insulin regulates insulin-like growth factor I mRNA in rat hepatocytes. Am J Physiol 1991;260(6 Pt 1):E846-51.

29. Brismar K, Fernqvist-Forbes E, Wahren J, Hall K. Effect of insulin on the hepatic production of insulin-like growth factor-binding protein-1 (IGFBP-1), IGFBP-3, and IGF-I in insulin-dependent diabetes. J Clin Endocrinol Metab 1994;79:872-8.

30. Holt RI, Simpson HL, Sonksen PH. The role of the growth hormone-insulin-like growth factor axis in glucose homeostasis. Diabet Med 2003;20:3-15.

31. Murphy LJ. The role of the insulin-like growth factors and their binding proteins in glucose homeostasis. Exp Diabesity Res 2003;4:213-24.

32. Rajpathak SN, Gunter MJ, Wylie-Rosett J, Ho GY, Kaplan RC, Muzumdar R, et al. The role of insulin-like growth factor-I and its binding proteins in glucose homeostasis and type 2 diabetes. Diabetes Metab Res Rev 2009;25:3-12.

33. Frystyk J, Skjaerbaek C, Vestbo E, Fisker S, Orskov H. Circulating levels of free insulin-like growth factors in obese subjects: the impact of type 2 diabetes. Diabetes Metab Res Rev 1999;15:314-22.

34. Rajpathak SN, He M, Sun Q, Kaplan RC, Muzumdar R, Rohan TE, et al. Insulin-like growth factor axis and risk of type 2 diabetes in women. Diabetes 2012;61:2248-54.

35. Munoz MT, Barrios V, Pozo J, Argente J. Insulin-like growth factor I, its binding proteins 1 and 3, and growth hormonebinding protein in children and adolescents with insulindependent diabetes mellitus: clinical implications. Pediatr Res 1996;39:992-8.

36. Gambaro G, Baggio B. Growth factors and the kidney in diabetes mellitus. Crit Rev Clin Lab Sci 1998;35:117-51.

37. Kanazawa I, Yamaguchi T, Sugimoto T. Serum insulinlike growth factor-I is negatively associated with serum adiponectin in type 2 diabetes mellitus. Growth Horm IGF Res 2011;21:268-71.

38. Dunger DB, Regan FM, Acerini CL. Childhood and adolescent diabetes. Endocr Dev 2005;9:107-20.

39. Cinaz P, Kendirci M, Kurtoglu S, Gokcora N, Buyan N, Yavuz I, et al. Serum levels of insulin-like growth factor-I and insulin-like growth factor binding protein-3 in children with insulin-dependent diabetes mellitus. J Pediatr Endocrinol Metab 1996;9:475-82.

40. Wedrychowicz A, Dziatkowiak H, Nazim J, Sztefko K. Insulin-like growth factor-1 and its binding proteins, IGFBP-1 and IGFBP-3, in adolescents with type-1 diabetes mellitus and microalbuminuria. Horm Res 2005;63:245-51.

41. Bereket A, Lang CH, Blethen SL, Fan J, Frost RA, Wilson TA. Insulin-like growth factor binding protein-3 proteolysis in children with insulin-dependent diabetes mellitus: a possible role for insulin in the regulation of IGFBP-3 protease activity. J Clin Endocrinol Metab 1995;80:2282-8. 
42. Kim MS, Lee DY. Serum insulin-like growth factor-binding protein-3 level correlated with glycemic control and lipid profiles in children and adolescents with type 1 diabetes. J Pediatr Endocrinol Metab 2014;27:857-61.

43. Payne JF, Tangpricha V, Cleveland J, Lynn MJ, Ray R, Srivastava SK. Serum insulin-like growth factor-I in diabetic retinopathy. Mol Vis 2011;17:2318-24.

44. Kim MS, Hwang PH, Lee DY. Clinical characteristics of type 2 diabetes in children identified by school urine glucose screening [abstract]. In: Program and Abstract, the 8th Congress of Asian Society for Pediatric Research; 2012 May 17-19, Seoul, Korea, Seoul: Asian Society for Pediatric Research, 2012;180. 